Check for updates

The BMJ

Cite this as: BMJ 2021;375:n2452 http://dx.doi.org/10.1136/bmi.n2452 Published: 07 October 2021

\title{
Covid-19: Vaccine advisory committee must be more transparent about decisions, say researchers
}

\section{Elisabeth Mahase}

The government has refused to release the minutes of the meeting in which its vaccine advisory committee decided not to recommend vaccinating all 12-15 year olds against covid-19. ${ }^{1}$

The UK Health Security Agency, which replaced Public Health England, rejected a freedom of information request for the document on the grounds that it intended to publish the minutes "in due course."

The agency argued that it was in the public interest to withhold the information until it could be released in a "simultaneous, coordinated manner" and that disclosing the minutes before they were finalised could "result in a false impression of the contents of the meeting." The decision is being appealed.

On 3 September the Joint Committee on Vaccination and Immunisation (JCVI) said that it would not be recommending universal vaccination for 12-15 year olds because although the health benefits of vaccination were "marginally greater than the potential known harms," the margin of benefit was considered too small. ${ }^{2}$ The committee did not explain what factors its conclusion was based on, and neither the minutes nor the data behind the decision have been made public. ${ }^{3}$

The JCVI asked ministers to seek further advice from the UK's chief medical officers on the wider potential benefits of vaccination. The government later (13 September) accepted the chief medical officers' recommendation to vaccinate all 12-15 year olds on the basis of an assessment that included transmission in schools and the effect on children's education. ${ }^{4}$

In a letter dated 5 October academics from Independent SAGE wrote to the JCVI highlighting the fact that, despite the committee's own policy stating that draft minutes would be published within six weeks of each meeting, the last publicly available minutes were from February 2021. ${ }^{5}$

They urged the JCVI to "abide by its code of practice and be open and transparent through rapid publishing of all agendas, supporting papers and minutes," arguing that "public confidence in vaccination programmes is assisted by clear and consistent processes and messaging."

They added, "In that spirit, we wish to have a public assurance from JCVI that all future considerations of covid-19 vaccines, including the extension of vaccination to children under 12 years of age, will be conducted openly and transparently."

bmj.com View and Reviews-Helen Salisbury: Official hesitancy is not helping (BM/2021;374:n2366; doi:10.1136/bmj.n2366)
1 UK Health Security Agency. Freedom of information request-covid vaccines in 12-15 year olds. 6 Oct 2021. https://bit.ly/3uQvKvJ

2 lacobucci G. Covid-19: JCVI opts not to recommend universal vaccination of 12-15 year olds. BMJ 2021;374:n2180.

doi: 10.1136/bmj.n2180 pmid: 34479872

3 Department of Health and Social Care. JCVI statement on covid-19 vaccination of children aged 12 to 15 years: 3 September 2021-considerations. 3 Sep 2021. https://www.gov.uk/government/publications/jcvi-statement-september-2021-covid-19-vaccination-of-childrenaged-12-to-15-years/jcvi-statement-on-covid-19-vaccination-of-childrenaged-12-to-15-years-3-september-2021\#considerations

4 lacobucci G. Covid-19: Vaccinating children will help end pandemic, says minister. BMJ 2021;374:n2254. doi: 10.1136/bmj.n2254 pmid: 34521631

5 Independent SAGE. Indie SAGE letter to JCVI. 5 Oct 2021. https://www.independentsage.org/wp-content/uploads/2021/10/Indie-SAGE-letter-toJCVI-.pdf

This article is made freely available for use in accordance with BMJ's website terms and conditions for the duration of the covid-19 pandemic or until otherwise determined by BMJ. You may use, download and print the article for any lawful, non-commercial purpose (including text and data mining) provided that all copyright notices and trade marks are retained. 